\title{
わかり易い公害分析・計測基礎講座 開講にあたって
}

日色 和 夫

現在の環境污染問題の解決にあたって，どんな污染物質がどの程度存在して いるか, 污染物質はどのような形態で存在しているかを知るてとがまず必要に なってくる. そこで污染物質の検出, 分析, 計測がきわめて重要視されている. 各種の文献あるいは著書などにはてれらの理論や技術についてのきわめて専門 的な解説がなされているが, 乙の種の記事はその分野にある程度の知識あるい は経験を持った人でないと理解できない面がある.

本講座は環境試料の分析・計測の実務にたずさわっている現場の技術者や， 今後乙の分野の仕事を始めようとする人達が, 分析・計測の操作を正しく行な うためにはどうしたらよいかをわかり易く解説することを目的として始められ るもので, 分析・計測の理論は理解し易いように説明し, 実際の操作はできる だけくわしく解説する予定である．また分析・計測の業務に直接関係していな い人達には，乙の仕事がいかに重要でありまたいかなる理論から組み立てられ た技術体系であるかを理解していただくことも目的としている.

広い意味での環境污染計測の中には悪臭の測定や騒音, 振動の計測も考えら れるであろうが, てれらあ含めるとかなり膨大なスペースを必要とし, 読者層 あ大きく変ることが予想されるので, 本講座では主として化学的手段による分 析技術を中心に解説することにした。

すなわち吸光光度法, 原子吸光法, ガスクロマトグラフ法, ポーラログラフ 法, イオン電極法, けい光 X線分析法, けい光光度法, 発光分光分析法, ガス マス法, さらにサンプリング法, 溶媒抽出法, BOD, COD 測定法, イオン 交換樹脂の使用法などの項目が予定されている.

本講座の多くの部分は環境技術編集委員会の提案に従い，私が菲才をかえり みず執筆することになったが, 私の専門から離れる分野については, その理論 ・技術に精通した方々の御協力を得て解説する予定である. 


\section{(第1蓝) 吸光 光度 法の化学}

日色和夫

(工業技術院大阪工業技術試験所特殊試薬研究室長)

\section{1. はじめに}

吸光光度法は比色法之も呼ばれている分析法で, 現 在環境污染物質の分析には最む広く利用されている方 法の一つである. 吸光光度法は, 分析しようとするイ オンと反応して色を出す特殊な試薬を試料溶液に加え ることによってそのイオンの存在目に比例する色を生

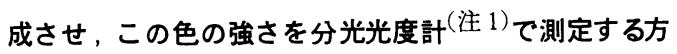
法である.

これをわかり易く図で示すと次のようになる。

$$
\text { 分析しようとするイオン }
$$

特殊な試薬

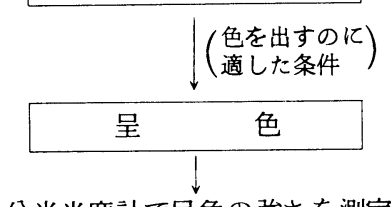

分光光度計で呈色の強さを測定

したがって吸光光度法をうまく行なうためには，分析 しようとするイオンと反応して色を出す試薬を正しく 選び，その試薬とイオンとが反応してイオンの存在量 に比例する色を生成する条件を適正没設し，そして 分光光度計で色の強さを測定する操作を正しく行なう ことなどが重要である.

以下てれらの事項について順を追って説明する.

\section{2. イオンと反応して呈色を示す試薬の選び方}

J I S K 0102-1974 の工場排水試験方法を見ると， たとえばシアンの分析にはピリジンーピラゾロン法,リ ンの分析にはモリブデン青法, あるいはクロムの分析 にはジフェニルカルバジド法などの方法が示されてい
るが, てれらはいずれ屯分析しようとするシアン, リ ン,クロムなどと反応して色を出す試薬の名前, ある いは生成した呈色化合物の名前をとって名付けられて いる.

シアンの分析になぜピリジンーピラゾロン試薬が用 いられているか, あるいはなぜリンの分析にモリブデ ン青法がよいか,などは数多くの基礎的な研究の結果 決められたあのであるが，どのような呈色用試験がよ いかを判断するには表 1 亿示したような条件が考慮さ れねばならない，以下これらの条件についてくわしく 説明する。

表 1 吸光光度分析に使用される 呈色試薬に必要な条件
（1）呈色が強い
(2) 呈色が安定である
（3） 定量目的イオンとのみ呈色反応する
（4）呈色反応条件か䗅密でない
(5) 入手が容易で安定である
(6) 無害である

（1）その試薬で生成する呈色ができるだけ強いこと. たとえばアンモニアの分析には次亜塩素酸ナトリウム ーナトリウムフェノラート試薬とネスラー試薬が広く 利用されているほか, 次亜塩素酸ナトリウムーチモール 試薬などあ用いられている. しかし一定量のアンモ二 ア，たとえば 1 モルのアンモニアから生成する呈色の

（注 1 ）溶液の色の強さを正確に測定する装置で, 光源ランプ から出た光を分光器で分光して適当な波長の光とし, てれをガ ラス製のセルに入れた着色溶液にあて, 溶液を通過した光の強 さを光電管で測定するものである，光源の光の強さから溶液を 通った後の光の強さを差引けば溶液で吸収された光の量, すな わち呈色の強さがわかる. 詳しくは第2講で解説する予定. 
強さ（これは通常, 後で述べるモル吸光係数であらわ される）には差がある.すなわち次亜塩素酸ナトリウ ムーナトリウムフェノラート試薬で得られる呈色の強 さをかりに 100 とすると, ネスラー試薬で得られる呈 色の強さは約 50 であり, 次亜塩素酸ナトリウムーチモ ールによる呈色の強さは約 250 である．別の考え方を すれば同じ呈色の強さ，たとえば 1.0 の強さの呈色を 生成するのに必要なアンモニア量が，かりに次亜塩素 酸ナトリウムーナトリウムフェノラート試薬で $0.1 \mathrm{mg}$

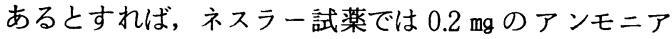
が必要であり, 次亜塩素酸ナトリウムーチモール試薬で は $0.04 \mathrm{mg}$ でよいということになる.したがって強い呈 色を生成する試薬を用いるとそれだけ微量のシアンま で測定できるわけで, その試薬の感度が高いというこ とができる。

（2）試薬とイオンとが反応して生成した呈色を測定 するのに必要な時間の間, その呈色が安定で, 強くな ったり弱くなったりしないてと. 普通呈色の強さを測 定するのに，1 個の試料だけだと 2 〜 分ですむが, 大低の場合数個あるいは10個というように多数の試料 を測定するので，少くとも30分位測定に必要であるが， この間に先に測定した試料と後で測定した試料とで同 じイオン量の呈色の強さが変るようでは正確な分析が できないからである.

(3) 分析しようとするイオン以外のイオンと反応し て同じような呈色を生成しない試薬であること，環境 污染物質の分析を行なう多くの場合, 分析しようとす るイオン以外に数多くの共存イオンがあって，てれら が試薬と反応して同じ色を生成したならば，分析目的 イオン量が実際より多く存在しているというように, 間違った結果を出してしまう。たとえばリンの分析の 場合は検水にモリブデン酸アンモニウムと塩化第一ス ズの試薬を加えて生成する青色，すなわちモリブデン 青の色の強さを測定するが， 検水中にヒ素が存在する とリンと全く同様の青色を生成するのでリンの量が実 際より多く測定される。したがって大量のヒ素が存在 する試料中のリンをモリブデン青法で測定することは できないので，七素を適当な方法で除いた後分析しな ければならない.

（4）試薬とイオンとが呈色を生成する反応条件があ まり厳密でないこと. 反応溶液の $\mathrm{pH}$ が少し変ったり, 温度のわずかな高低によって呈色の強さが大きく変化 するような場合は, これらの条件を厳密に一定にして 呈色を生成させねばならない，したがって分析操作が
難かしくなる

（5）試薬の入手が容易で純品が得られ，また安定で あること、いかにすぐれた性質を持った試薬であ非常 に高価であれば実際上分析にふんだんに使用すること はできない，また試薬の純度が低いと，試薬中の不純 物が妨害の呈色を生成したり他のイオンと呈色するお それがあるほか, 試薬の製造元や製品ロットルより純 度が変るために同一量の試薬を加えたつもりでも添加 量が異なることがあるので呈色の強さが変化する。 た試薬が不安定であれば分解してしまった試薬を知ら ずに使用するおそれがあるので，つねに新品を用意し ておかねばならない，また試薬溶液が保存中に分解す るようでは, 使用のつど溶液を調製しなければならな い不便さがある.

（6）以上のほかの条件としては試薬が有害でないこ と，ピリジンのように悪臭を発するものでないてと， などの条件も考慮されねばならない。

以上述べたように, 吸光光度分析に用いられる試薬 は，多くの条件を満足しているものでなければならな いが，実際にてれらの条件をすべて兼ねそなえた試薬 はほとんどない，たとえばシアンの定量に広く用いら れているピリジンーピラゾロン試薬は呈色が強いとい う前記の(1)の条件は満たしているが，亜硝酸イオンな どのシアン以外のイオンとあ反応して呈色を生成する， 温度の変化によって呈色の強さが変る, 試薬溶液が分 解しやすい，覀臭のあるピリジンを使用する，などの 欠点のため, それぞれ前記(3)，(4)，(5)，(6)などの条件 を満足していない.

また鉄の定量に用いられる 1,10-フェナントロン(また はのーフェナントロリン)試薬は呈色が安定であり,鉄との 反応条件ああまり厳密ではなく,また試薬はきわめて安 定で純品が入手できるなどの長所があるので, 前記の(2), (4),(5)の条件を満足している. しかし，1,10-フェナント ロリンを改良した 4, 7 -ジフェニル-1,10-フェナントロリン (別名バソフェナントロリン) 試薬や $2,4,6$-トリス(2-ピリジル) - $s$-トリアジン（別名TPTZ）試薬に くらべると呈色が弱いという欠点や, ニッケル, コバ ルト，銅とあ反応して呈色を生成するという欠点があ るので, 前記の(1), (3)の条件は満足していない.

このように J IS 法その他多くの公定分析法で採用 されている呈色用試薬は何らかの欠点を持っているが, 他によい試薬がないために仕方なく使用しているとい うのが実情である. したがって吸光光度分析を行なう にあたっては，使用する試薬の欠点は何かということ 
を十分知った上て，その欠点を分析操作上でできるだ け無くするように注意すればよい. 表 2 には現在広く
用いられている吸光光度分析用試薬の主な長所と短所 を概念的にまとめて示した.

表 2 吸光光度分析用試薬の主な長所と短所, ならびにモル吸光俰数

\begin{tabular}{|c|c|c|c|c|}
\hline 試 薬 名 & $\begin{array}{l}\text { 測定目的 } \\
イ \text { オ }\end{array}$ & 長 所 & 主 & $\begin{array}{l}\text { モル 吸光 係 数 } \\
\text { (測定波長 } \mathrm{nm} \text { ) }\end{array}$ \\
\hline ネスラー & アンモニア & $\begin{array}{l}\text { 呈色反応条件が厳密でな } \\
\text { い }\end{array}$ & 他物質と呈色反応する & $2,200 \quad(425)$ \\
\hline $\begin{array}{l}\text { 次亜塩素酸ナトリゥリウム } \\
\text { トリウムフェート }\end{array}$ & アンモニア & $\begin{array}{l}\text { 比較的他物質と呈色反応 } \\
\text { しない }\end{array}$ & 試薬溶液が不安定 & $4,800 \quad(625)$ \\
\hline $\begin{array}{l}\text { スルファニル酸 }-\alpha-ナ フ \\
\text { チルアミン }\end{array}$ & 亜硝酸 & 呈色が強い & 他物質と呈色反応する & $41,000 \quad(520)$ \\
\hline $\begin{array}{l}\text { ブル シン } \\
\text { モリブデン酸アンモ }\end{array}$ & 硝酸 & 呈色が胎! & $\begin{array}{l}\text { 呈色反応条件が厳密 } \\
\text { 七素とあ呈色反応する }\end{array}$ & $\begin{array}{r}620^{* 1}(410) \\
24000^{* 2}(700)\end{array}$ \\
\hline 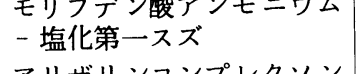 & & 至巴が蚛 & & \\
\hline $\begin{array}{l}\text { アリザリンコ } \\
\text { ピリジンーピ }\end{array}$ & フッ化物 & 比較的呈色が強い & 物質が多い & $9,100 \quad(620)$ \\
\hline $\begin{array}{l}\text { ピリジンーピン } \\
\text { チオシアン酸第 }\end{array}$ & & 呈色九 & 安定 & $47.000 \quad(620)$ \\
\hline $\begin{array}{l}\text { チオシアン酸第 } \\
\text { クロム酸バリウ }\end{array}$ & $\begin{array}{l}\text { シアン } \\
\text { 硫酸 }\end{array}$ & $\begin{array}{l}\text { 試薬溶液が安定 } \\
\text { 呈色が安定 }\end{array}$ & $\begin{array}{l}\text { 呈色が弱い } \\
\text { 妨害物質が多い }\end{array}$ & $\begin{array}{rr}1,700 & (460) \\
960 & (370)\end{array}$ \\
\hline $\begin{array}{l}\text { ジエチルジチオカルハ } \\
\text { 酸ナトリウム }\end{array}$ & 銅 & 比較的呈色力強い & $\begin{array}{l}\text { ビスマスとも呈色反応 } \\
\text { する }\end{array}$ & $13,000^{* 3}(430)$ \\
\hline ジチゾン & 临鉛 & 呈色が強い & 他物質と呈色反応する & $93,000 * 3(530)$ \\
\hline ジンコン & 亜 & 呈色が強く安定 & 他物質と呈色反応する & $46,000 \quad(610)$ \\
\hline ジチゾン & 鉛 & 呈色 & 呈色が不安定 & $57,000^{* 3}(530)$ \\
\hline ジチゾン & カドミウム & 呈色が強い & 呈色操作条件が厳密 & $50,000 * 3(530)$ \\
\hline $\begin{array}{l}\text { ジメチルグリオキシム } \\
\text { 二トロソ } \mathrm{R} \text { 塩 }\end{array}$ & $\begin{array}{l}\text { ニッケル } \\
\text { コバルト }\end{array}$ & $\begin{array}{l}\text { 他物質と呈色反応しない } \\
\text { 比較的呈色が安定 }\end{array}$ & $\begin{array}{l}\text { 呈色が不安定 } \\
\text { 他物質と呈色反応する }\end{array}$ & $\begin{array}{l}16,000 *(470) \\
30,000 * 5(420)\end{array}$ \\
\hline $\begin{array}{l}\text { ニトロソR } \\
\text { ヨウ化カリウム }\end{array}$ & & 他物質と呈色反応しない & 比較的呈色が弱い & $8,000 * 3(460)$ \\
\hline ジチゾン & & 呈色 & & $\begin{array}{ll}40,000 & (500) \\
60,000 \quad(500)\end{array}$ \\
\hline フェニルフル & & 比較白 & 正 & $\begin{array}{rr}60,000 & (500) \\
1,200 & (545)\end{array}$ \\
\hline 過ヨウ素酸力 & マンガン & 色反応しない & 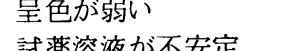 & $\begin{aligned} 1,200 & (545) \\
11,000 & (450)\end{aligned}$ \\
\hline ホルムアルド & マンガン & 比較的呈白 & $\begin{array}{l}\text { 總不安定 } \\
\text { 色が弱い }\end{array}$ & $\begin{array}{ll}11,000 & (450) \\
10,000 & (500)\end{array}$ \\
\hline $\begin{array}{l}1,10 \text {-フェナ } \\
\text { リブデン }\end{array}$ & $\begin{array}{l}\text { 鉄 } \\
\text { 七素 }\end{array}$ & $\begin{array}{l}\text { 試薬が純粋で安定 } \\
\text { 呈色が強い }\end{array}$ & $\begin{array}{l}\text { 比較的呈色が弱い } \\
\text { 呈色操作条件が厳密 }\end{array}$ & $\begin{array}{l}10,000 *(500) \\
24,000 * 3(735)\end{array}$ \\
\hline 一塩化第一スズ & & 等 & & \\
\hline $\begin{array}{l}\text { ジェチルジチオカルバミン } \\
\text { 酸銀 }\end{array}$ & ヒ素 & $\begin{array}{l}\text { 呈色操作条件が厳密でな } \\
\text { い }\end{array}$ & ピリジンの悪臭がある & $13,000 \quad(540)$ \\
\hline ローダミンB & アンチモン & 妨害物質が少ない & & $73,000 * 3(550)$ \\
\hline オキ シン & アルミニウム & 呈色が安定 & 他物質と呈色反応する & $6,300^{* 3}(390)$ \\
\hline ジフェニルカルバジド & クロム & 呈色が強い & 呈色反応条件が厳密 & $26,000 \quad(530)$ \\
\hline 3, 3'-ジアミノベン & セレン & 他物質と呈色反応しない & 呈色操作条件が厳密 & $7,900 * 3(420)$ \\
\hline 0-フェニレ & セレン & 呈色が強い & 呈色操作条件が厳密 & $16,000 * 3(335)$ \\
\hline & モリブデン & $\begin{array}{l}\text { 比較的他物質と呈色反応 } \\
\text { しない }\end{array}$ & 呈色反応条件が厳密 & $17,000^{* 3}(470)$ \\
\hline チオシアン酸ナトリ & タングステン & $\begin{array}{l}\text { 比較的他物質と呈色反応 } \\
\text { しない }\end{array}$ & 呈色反応条件が厳空 & $18,000^{* 3}(400)$ \\
\hline $\begin{array}{l}\text { 亜硝酸ナトリウム } \\
\text { チンンブルー }\end{array}$ & $\begin{array}{l}\text { ヨウ化物 } \\
\text { ホウ素 }\end{array}$ & $\begin{array}{l}\text { 他物質と呈色反応しない } \\
\text { 呈色が強い }\end{array}$ & $\begin{array}{l}\text { 呈色が弱い } \\
\text { 呈色操作条件が厳密 }\end{array}$ & $\begin{array}{r}440^{* 3}(520) \\
83,000^{* 3}(660)\end{array}$ \\
\hline
\end{tabular}

*1＼cjkstart検量線が曲がるので, 正確な値は求められない。

*2 J I S K 0102 の ( b ) 法で得られる値.

*3 抽出操作が入るので有機相中での值.

*4 J IS K 0102 のA法で得られる値.

*5 J IS K 0120 のA法で得られる值. 


\section{3. イオンと試薬との呈色反応の化学}

分析しようとするイオンと試薬とが反応して色を生 成するのは，イオンと試薬とが何らかの形で結合して 色の着いた化合物ができるためである．たとえばセレ ンを $3,3^{\prime}-$ - ジアミノベンチジン 試薬で分析する場合 には,以下のような反応が行なわれている。

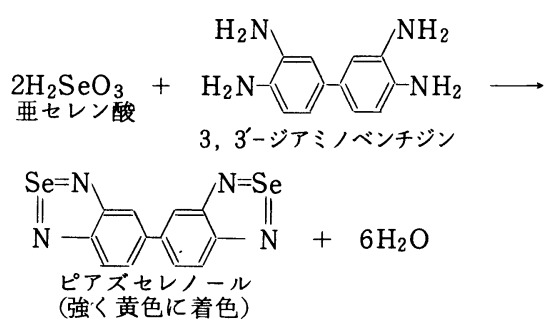

すなわち亜セレン酸 2 分子と $3,3^{\prime}$ - ジアミノベン チジンの 1 分子が反応して強く黄色に着色したピアズ セレノール 1 分子よ水 6 分子が生成する. 亜セレン酸 2 分子から 1 分子のピアズセレノールが生成するので, セレン量が多ければそれだけピアズセレノールが多量 に生成し，そのぶん黄色の着色の強さを測定すればセ レン量が測定できるととになる。

ここに生成した黄色のピアズセレノールのような化 合物は金属と試薬とが結合したもので，キレート化合 物と言われている.

別の呈色反応の例としてアンモニアをフェノール法 で分析する場合を解説しょう．定量操作法では検水に 次亜塩素酸ナトリウムとナトリウムフェノラートを加 えて振り混ぜて放置した後, 溶液の色の強さを測定す ることになっているが, この場合の反応は以下のとお りである.まずアンモニアと次亜塩素酸ナトリウムと が反応してモノクロラミンができる.

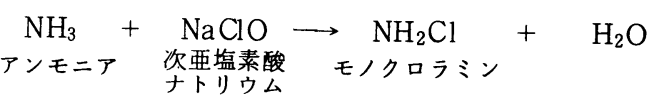

つぎにこのモノクロラミンがナトリウムフェノラート, 次亜塩素酸ナトリウムと反応してキノンクロラミンが 生成する.

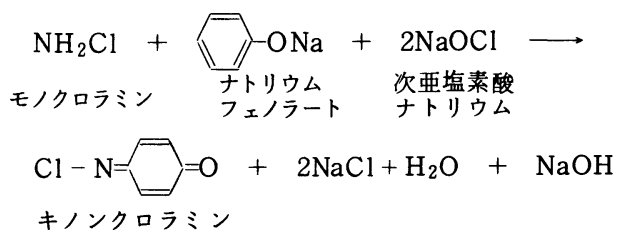

さらにこのキノンクロラミンがもう 1 分子のナトリウ ムフェノラートと反応してインドフェノール青が生成 する.わかり易いようにナトリウムフェノラートを先 に書くと次のようになる.

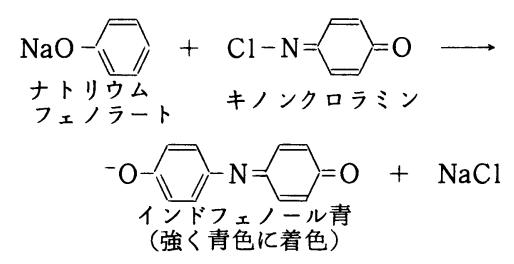

このインドフェノール青が強く青色に着色している ので，その青色を測定することによりアンモニアを分 析することができる.

このインドフェノール青は色素の一種で, 先のセレ ンの場合の例のように金属が試薬と結合したキレート とは別種の化合物である.

さらにあう 1 つ例として, ローダミンB試薬によ るアンチモンの分析の場合をあげよう。この場合は前 の 2 つの例とやや異なっていて, アンチモンとローダ ミンBとが反応して着色した化合物ができるのではな く, ローダミンB自身か始めから強く紫色に着色して おり，これがアンチモン（正確にはへキサクロロアン チモン）と結合したとき, その着色はほとんど変化し ないが他の化学的性質が大きく変るのである.すなわ ちローダミン Bは水に可溶性であるが, アンチモンと ローダミンBの結合した化合物は水に不溶性となり逆 に有機溶媒に可溶性となる。したがってアンチモンを 含む検水にローダミン Bを加えイソプロピルエーテル のような有機溶媒を加えて抽出すると, アンチモンと ローダミンBとが結合したものだけか有機溶媒に溶け て抽出され，アンチモンと結合していないローダミン Bは抽出されないで水相に残る. そのため検水中のア ンチモンが多ければそれだけ多くのローダミンBがア ンチモンと結合して有機溶媒に抽出されるので, 有機 溶媒がそのぶんだけ強く紫色に着色する．すなわち有 機相の着色の強さは検水中のアンチモン量に比例する わけである.

以上の反応を化学式で示すと次のようになる.

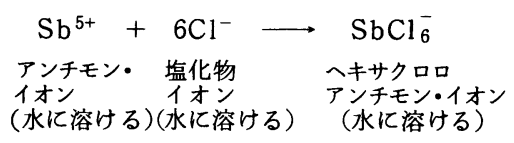




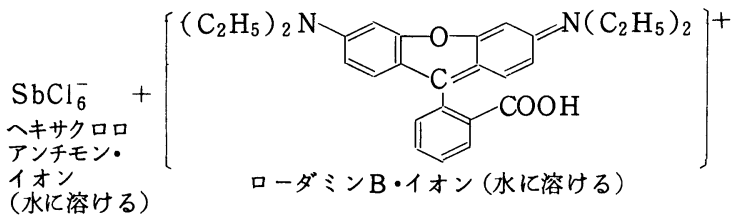

$\rightarrow\left[\left(\mathrm{C}_{2} \mathrm{H}_{5}\right)_{2} \mathrm{~N}\right.$

ローダミンB-ヘキサクロロアンチモン・イオン対化合物 （水に溶けない，有機溶媒に溶ける）

すなわち，まずアンチモン・イオンが塩化物イオンと 反応してへキサクロロアンチモン・イオンが生成する. これは 1 価の陰イオンであるが, 1 価の陽イオンであ るローダミンBイオンと反応してローダミンB-ヘキ サクロロアンチモン・イオン対化合物ができる，乙の 化合物が有機溶媒に抽出され, 有機溶媒が紫色に着色 する

この化合物はへキサクロロアンチモンの負の 1 価の 荷電とローダミンBの正の 1 価の荷電とが引き合い, 電気的に中和されて全体として荷電のない大きな分子 となったと考えることができる．乙のように複雑な構 造の大きな陽イオンと陰イオンとが結合して生成する 電気的に中性の化合物をイオン対化合物之呼ぶ.

以上述べたように，イオン上試薬とが反応して生成 する呈色化合物には, セレンの場合のようなキレート 化合物, アンモニアの例で示した色素, およびアンチ モンの場合のイオン対化合物などがある. これら 3 種 類に入らない呈色化合物は比較的少ない，吸光光度分 析法を十分に理解するためには, 分析しようとするイ オンと試薬とが反応して生成する呈色化合物がどうい う種類のものであるかを知ることが重要である.

\section{4. 吸光光度法の感度}

さきに，イオン反応して呈色を示す試薬の選び方の ところで，上゙のような呈色試薬がよいかを判断する基 準を(1)から(6)まで述べた。 これらのうちで(1)の条件, すなわち分析しようとするイオンと試薬とで生成する 呈色が強いという条件が, 微量の環境污染物質を分析 する場合にはきわめて重要と考えられる.

呈色の強さを比較するには，前にあ述べたようにモ ル吸光係数の值を用いることが多い. モル吸光係数と は，長さ（光路の長さ）が $1 \mathbf{c m}$ の吸収セルを用いて， その呈色化合物の漊度が $1 \mathrm{M}$ の溶夜の吸光度 (注2)を測
定したときに示される吸光度である. モル吸光係数の 値を測定するには，実際に $1 \mathrm{M}$ の呈色化合物溶液を作 ってその吸光度を測定するのではなく，っと希薄な 溶液，たとえば $1 \mathrm{M}$ の分の 1 とか 1 万分の 1 ，ある いは10万分の 1 の希薄な呈色化合物溶液を作成してそ の吸光度を測定し，その值を千倍，1 万倍あるいは 10 万倍してモル吸光係数を求める.

いま $2 \sim 3$ の例でモル吸光係数の求め方を説明しよ う.たとえばマンガンの吸光光度分析をするのに，ホ ルムアルドキシム試薬を用いたとする．そしてマンガ ンとホルムアルドキシムの呈色化合物の吸光度を $1 \mathrm{~cm}$ のセルを用いて測定し, 溶液 $50 \mathrm{ml}$ 中のマンガン量が50 $\mu \mathrm{g}$ のとき 0.2 の值を得たとする. 溶液 $50 \mathrm{ml}$ 中 $50 \mu \mathrm{g}$ の ンガン濃度は $1 \mathrm{ppm}$ であり, これをモル濃度に換算す ると約 $1.8 \times 10^{-5} \mathrm{M}$ とな（マンガンの原子量は約 55 であるので $55 \mathrm{ppm}$ が $10^{-3} \mathrm{M}$ である，すなわち「すべて の元素や分子について原子量あるいは分子量のppm値

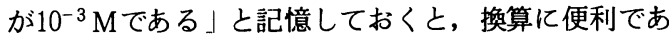
る).乙の $1.8 \times 10^{-5} \mathrm{M}$ 濃度の場合の吸光度が 0.2 で あるならば, $1 \mathrm{M}$ 場合の吸光度はいくらになるかを 比例計算で求めると, 約 11,000 という值が得られる. これがマンガンとホルムアルドキシムとが反応して生 成した呈色化合物のモル吸光係数である。乙れをあう 少しわかり易く示すと次のようになる.

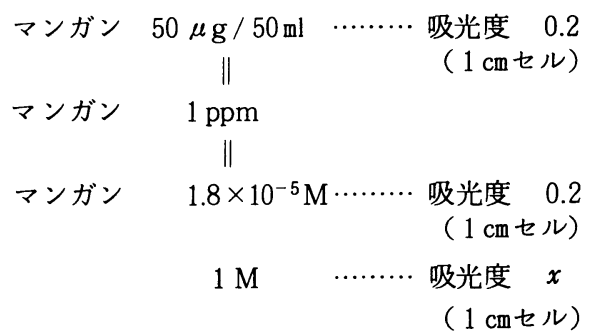

$$
x=\frac{0.2}{1.8 \times 10^{-5}} \fallingdotseq 11,000 \text { (モル吸光係数 }
$$

別のマンガンの吸光光度分析法として, 過ヨウ素酸力 リウム試薬による場合を考えよう。長さ $3 \mathrm{~cm}$ のルを

（注 2 ）吸光度は溶液を通った光がその溶液によってどれだけ 吸収されたかを示す度合である。溶液を通る前の光の強さを $\mathrm{I}_{0}$ ， 溶液を通った後の光の強さを I とすると, 吸光度 $\mathrm{A}$ は次式で表 わされる， $\mathrm{A}=-\log \left(\mathrm{I} / \mathrm{I}_{0}\right)$. 後出のランバート・ベールの法 則の概念図であ示すように，50\%の光が透過したときは I/ I $=0.5$ で $\mathrm{A}=0,3,25 \%$ の光が透過したときは $\mathrm{I} / \mathrm{I}_{0}=0.25$ で $\mathrm{A}=0.6$ となる．また $100 \%$ の光が透過したとき（溶液により 全く吸収されないとき）は $\mathrm{I} / \mathrm{I}_{0}=1.0$ で $\mathrm{A}=0.0$ となる. 
用いて吸光度を測定したとき，溶液 $100 \mathrm{ml}$ 中 $150 \mu \mathrm{g}$ のマンガン濃度で吸光度が 0.1 であった. このときのモ ル吸光係数はいくらか. まず $100 \mathrm{ml}$ 中 $150 \mu \mathrm{g}$ のマン ガン濃度は $1.5 \mathrm{ppm}$ であるので, 乙れをモル濃度に直 すと約 $2.7 \times 10^{-5} \mathrm{M}$ となる $2.7 \times 10^{-5} \mathrm{M}$ のとき吸光 度が 0.1 であるので, $1 \mathrm{M}$ のきの吸光度を計算する と 3,700となる.乙こで注意しなりればならないのは, この場合は長さ $3 \mathrm{~cm}$ のルを用いていることである. モル吸光係数は $1 \mathrm{~cm}$ のルの場合という定義であるの

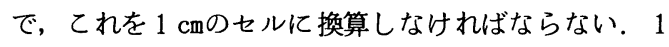
$\mathrm{cm}$ のルを用いたときの吸光度は $3 \mathrm{~cm}$ のルの場合の 3 分の 1 になるので, 3,700 の 3 分の 1 で約 1,200 とな り,てれがモル吸光係数である. 以上を示すと次のと おりである.

$$
\begin{aligned}
& \text { マンガン } 150 \mu \mathrm{g} / 100 \mathrm{ml} \cdots \cdots \cdots \text { 吸光度 } 0.1 \\
& \text { II ( } 3 \mathrm{~cm} \text { セル) } \\
& \text { マンガン } 1.5 \mathrm{ppm} \\
& \text { マンガン } \quad 2.7 \times 10^{-5} \mathrm{M} \cdots \cdots \cdots \text { 吸光度 } 0.1 \\
& \text { ( } 3 \mathrm{~cm} \text { セル) } \\
& 1 \mathrm{M} \quad \cdots \cdots \cdots \text { 吸光度 } x \\
& \text { ( } 3 \mathrm{~cm} \text { セル) } \\
& \begin{aligned}
x=\frac{0.1}{2.7 \times 10^{-5}} \doteqdot & 3,700 \\
& (3 \mathrm{~cm} \text { セル }) \\
& \| \\
& 1,200 \text { 〔モル吸光係数〕 } \\
& (1 \mathrm{~cm} \text { セル })
\end{aligned}
\end{aligned}
$$

以上説明したようにマンガンの吸光光度分析をする 場合, ホルムアルドキシム試薬を用いればモル吸光係 数が11,000であり, 過ヨウ素酸カリウムを用いれば モル吸光係数が 1,200 と決定された. モル吸光係数は $1 \mathrm{M}$ 呈色化合物溶液に相当する吸光度であるので, この値が高いほどそれだけ呈色が強いわけで, マンガ ンの場合はホルムアルドキシム試薬の方が過ヨウ素酸 カリウム試薬より約 9 倍も呈色が強い, それだけ感度 が高いと言うことができる.

先の表 2 には, このようにして計算したモル吸光係 数の値屯示しておいた。計算に用いた吸光度の值は J I S K 0102-1971 の工場排水試験方法の解説によ った.

\section{5. ランバート・ベールの法則}

さて, 先のモル吸光係数の計算のところで, お気付 きになった読者も多いと思うが，セルの中に入ってい
る呈色化合物の濃度がかりに千倍になれば呈色の強さ, すなわち吸光度も当然千倍になるということを前提に して計算を行なった．またセルの長さがかりに 3 倍に なれば吸光度も 3 倍になるということも仮定した．果 しててのような仮定が正しかっただろうか，実はこの 仮定はランバート・ベールの法則に従えば正しかった のである

ランバート・ベールの法則を詳細に述べるとかなり 複雑になるので, ここでは概念的な理解に止めておて う. すなわちランバートの法則では, セルを通った光 が呈色溶液で吸収される度合, すなわち吸光度は, セ ルの厚さに比例すると規定しており, ベールの法則で は，セルを通った光が呈色溶液で吸収される度合，す なわち吸光度は，呈色化合物の䢅度に比例する，と規 定しているのである

これを図解すると次のようになる.

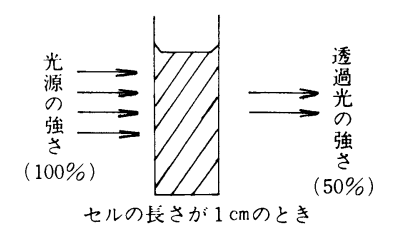

$50 \%$ 光が透過し，した がって50\%の光が吸収さ れる. これを吸光度に計 算し直すと約 0.3 となる.

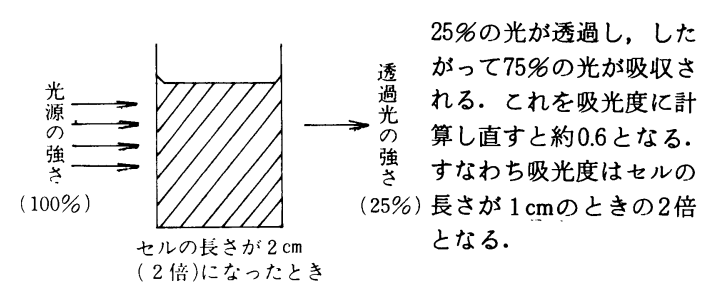

ランバートの法則の概念図
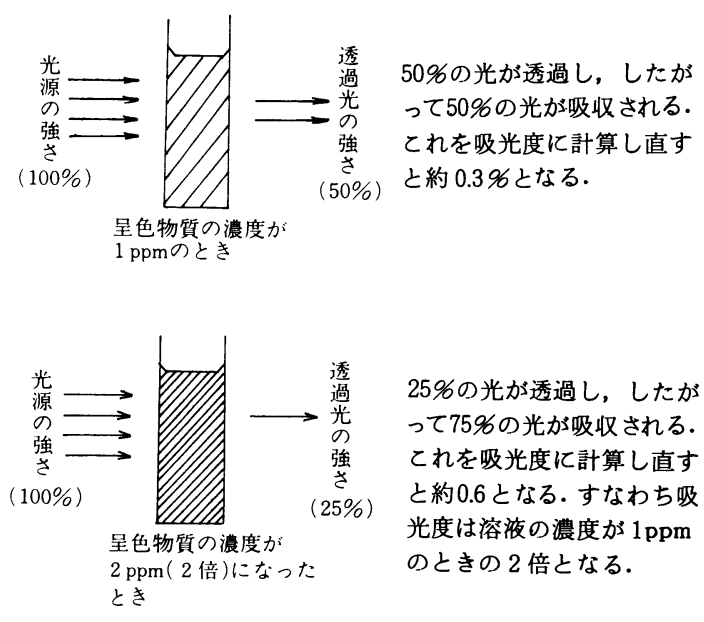

ベールの法則の概念困 
ランバートの法則とベールの法則のうち，とくにベ ールの法則が重要である．すなわち実際の分析の操作 では大低の場合 $1 \mathrm{~cm}$ の長さのセルを使用しており, セ ルの長さを変えることは少ないが, 呈色化合物の濃度 は常に変化しているからである.

吸光光度法であるイオンを定量する場合，あらかじ めそのイオンの濃度のわかっている標準溶液を用いて 定められた操作法に従って呈色化合物溶液を作り，そ の吸光度を測定し, 吸光度を測定した溶液中のイオン 濃度と吸光度との関係図, すなわち検量線(注3)を作成 する.図-1にはその一例として1,10-フェナントロリン試 薬を用いて鉄を定量する場合の検量線を示した，横軸 に吸光度を測定した溶液中の鉄イオンの濃度をとり, 縦軸に吸光度をとっている.

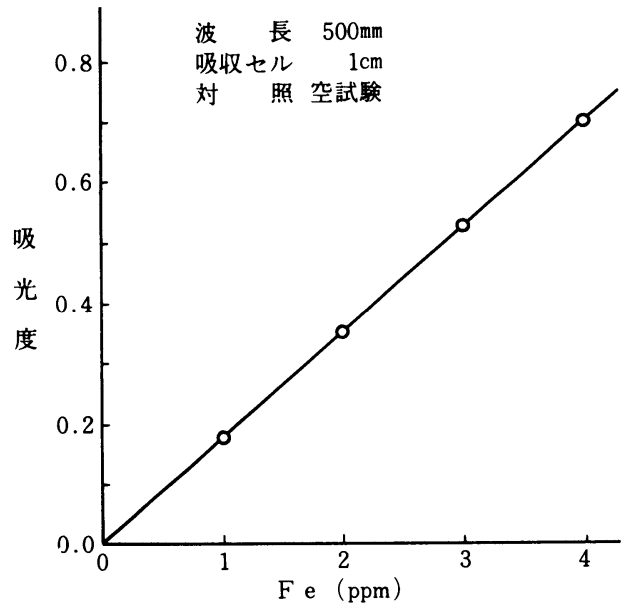

図-1 1,10-フェナントロリン試薬による鉄定量の 検量線の一例

ての図からわかるように，鉄の濃度が大きくなれば それに比例して吸光度も大きくなっているので, 検量 線はある一定の傾斜を持った直線となる.乙れは 1,10 フェナントロリン試薬で鉄を定量する場合, ベールの 法則が成立しているからである. 逆にベールの法則が 成立しない例としてブルシン試薬による硝酸イオンの 定量の際の検量線を図一2に示した。

乙の場合, 吸光度を測定した溶液中の硝酸イオン濃 度が $20 \mathrm{ppm}$ のときの吸光度は約 0.2 であるが, 硝酸 オン濃度が 2 倍の $40 \mathrm{ppm}$ になったときの吸光度は約 0.35 で, 0.2 の 2 倍の 0.4 になっていない.すなおち ベールの法則が成立していないので，乙のように検量 線が曲線となっているのである.

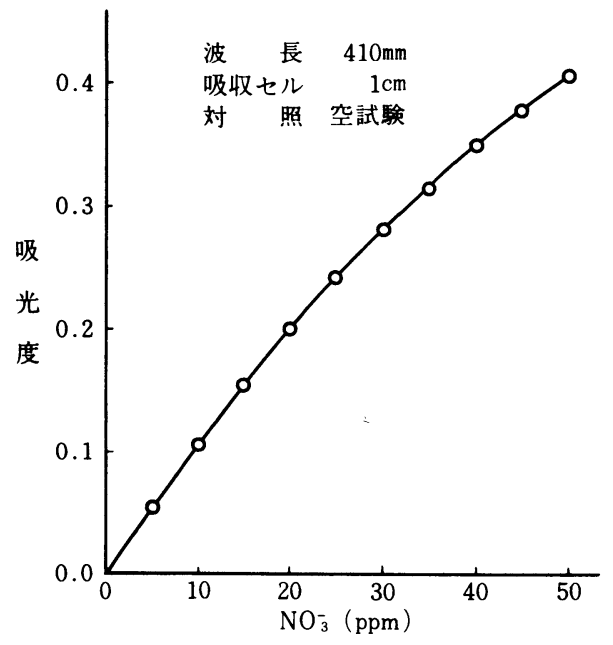

図-2 ブルシン試薬による硝酸イオン定量の 検量線の一例

このようにベールの法則が成立しない場合は, 検量 線を作るときに多数の測定を行なわないと正確な検量 線ができないので，よい定量法とは言えない．多くの 場合, 分析しようとするイオン濃度と吸光度との間に ベールの法則が成立するので検量線は直線となり，ブ ルシン試薬による硝酸イオンの定量の場合のように検 量線が曲るととは比較的少ない.

(以下次号)
（注 3 ）検量線はイオン濃度一吸光度の関係を示すグラフで, 通常吸光光度分析を行なう場合，まず測定しょうとするイオン の濃度が正確にわかっている標準溶液を用いて検量線を作成し ておき，つぎに分析試料の吸光度を測定する，そして検量線上 でその吸光度に相当するイオン濃度を求める。 